\title{
Darío de Regoyos y la pintura europea en la crisis de 1900
}

Manuel Valdés Fernández

RESUMEN. Entre 1870 y 1913 los sistemas de representación heredados de la Edad Moderna hicieron crisis ante el empuje de las radicales transformaciones culturales que se estaban produciendo en Europa como consecuencia de las Revoluciones Industriales. Pese a la resistencia de los clientes tradicionales, como la Iglesia y el Estado, las academias y la crítica conservadora, pintores, escultores y marchantes se adentraron en nuevos territorios estéticos. Los reiterados viajes de Darío de Regoyos a París, Bruselas y Londres, fueron itinerarios a la búsqueda de la contemporaneidad.

Palabras clave: 1900, pintura contemporánea, post-impresionismo, España negra, Los XX.

RESUME. Entre 1870 et 1913 les systèmes de représentation hérités de l'Âge Moderne tombèrent en crise devant la poussée des radicales transformations culturelles que avaient eu lieu en Europe comme conséquence des révolutions industrielles. Malgré la résistance des clients traditionnels, comme l'Église ou l'État, les académies et la critique conservatrice, les peintres, sculpteurs et marchands pénétrèrent dans de nouveaux territoires esthétiques. Le voyages continuels de Darío de Regoyos à Paris, Bruxelles et Londres, sont autant d'itinéraires à la recherche de la contemporanéité.

Mots clé: 1900, peinture contemporaine, post-impressionisme, Espagne noire, Les XX.

"Si volviera a comenzar mi vida, volvería a utilizar una paleta clara, sin tierras, sin negros, y solo haría paisaje, entregándome por completo a las impresiones que recibiera de la naturaleza", (Darío de Regoyos y Valdés, "Encuesta sobre las tendencias actuales en las artes plásticas", Mercure de France, 1905).

En el año 1879 Darío de Regoyos (Ribadesella, 1857 - Barcelona, 1913) tomó una decisión de trascendental importancia para su biografía: viajar Bruselas. Atrás quedaban la llegada a Madrid de un adolescente riosellano, una carrera de arquitectura interrumpida por la muerte de su padre y la falta de vocación, y sus estudios en la Real
Academia de Bellas Artes de "San Fernan$\mathrm{do}^{\prime \prime}$.

-

${ }^{1}$ P. Mourlane Michelena, "Darío de Regoyos", Pintura vasca, Bilbao, 1919.- Juan de la Encina (R. Gutiérrez Abascal), "Guiard y Regoyos", Pintores y escultores vascos, Bilbao, 1921.- R. SORIANO, Darío de Regoyos. Historia de una rebeldía, Imprenta F. Peña Cruz, Madrid, 1921.- P. LAFOND, "Darío de Regoyos", Museum II, no. 8, Barcelona, 1921, (véase en Darío de Regoyos, Fundación Caja de Pensiones, Madrid, 1986).- L. SANTOS TORROELlA, "Darío Regoyos", en Maestros de la pintura moderna, Madrid, 1952.- A. GARCÍA MIÑOR, El pintor Darío de Regoyos y su época, Instituto de Estudios Asturianos, Oviedo, 1958.- J. ROF CARBAllo, "La España negra de Darío de Regoyos", Catálogo Galería Mayer, Madrid, 1961.- E. LAFUENTE FERRARI, "Regoyos", Catálogo Galería Biosca, Madrid, octubre de 1969.- M. 


\section{UN VIAJE AL ENCUENTRO DE LA MODERNIDAD}

Es difícil resumir en uno solo los motivos que empujaron a Darío de Regoyos a emprender el viaje a Bruselas. La necesidad vital e intelectual de buscar y encontrar la modernidad podría englobar todas las causas. Esa idea dirigió a Regoyos y a Iturrino hacia Bruselas, y a otros, como Adolfo

FERnÁndez AVEllo, Pintores asturianos II, Oviedo, 1971.- M. L. DE LUXÁN Y M. VALDÉS, “Darío de Regoyos entre la crítica y la literatura de su tiempo", Boletín del Instituto de Estudios Asturianos, (1974), pp. 3 a 17.- M. J. QUESADA MARTíN, “Cartas enviadas por Darío de Regoyos a Daniel Zuloaga (1904-1913), Boletín del Instituto de Estudios Asturianos, (1984), pp. 245 a 273.- F. FontbonA, "Regoyos en Cataluña", Darío de Regoyos, Catálogo de la exposición organizada por la Fundación Caja de Pensiones, Madrid, 1986, pp. 22 a 33.- F. Calvo Serraller, "Darío de Regoyos", en Darío de Regoyos, Catálogo de la exposición organizada por la Fundación Caja de Pension, Madrid, 1986, pp. 13 a 21.J. TUSELL, "Darío de Regoyos y la introducción del arte moderno en España", Fragmentos, no. 15 y 16, (1989), pp.150 a 192.- J. SAN NiCOLÁS SANTAMARÍA, "Darío de Regoyos - I", Maestros del arte de los siglos XIX y XX, Barcelona, 1990.- J. L. BERNAL, "Regoyos visto por Regoyos", Goya, no. 220, (1991), pp. 220-229.- M. PRADO VADILlO, Darío de Regoyos (sus cartas inéditas), Bilbao, 1994.- DARÍO DE REGOYOS, /I. TELLECHEA IDÍGORAS/, Darío de Regoyos: cartas inéditas a Manuel Losada, Ignacio y Daniel Zuloaga, Adolfo Guiard y Miguel de Unamuno/ introducción, edición, notas e índices por J. Ignacio Tellechea Idígoras, Donostia/San Sebastián, 1994.- J. SAN NiCOLÁs, "Darío de Regoyos (1857-1913) y su participación en la modernización del arte", en Paisaje y figura del 98, Madrid, 1997, pp. 93 a 100.- J. SAN NICOLÁs, "Darío de Regoyos: un español en los orígenes del arte moderno en Europa", Los XX. El nacimiento de la pintura moderna en Bélgica, Madrid, 2001, pp. 91 a 135.- M. PRADO VADILLO, Tradición y modernidad en la pintura de Darío de Regoyos, Museo Nicanor Piñole, Gijón, 2002.- V. BOZAL, "Darío de Regoyos en la pintura española", Darío de Regoyos, Catálogo de la exposición organizada por Fundación Cultural Mafre Vida, Madrid, 2003, pp. 10 a 21.- I. MORENO RUIZ DE EGUINO, "Darío de Regoyos y el País Vasco", Darío de Regoyos, Catálogo de la exposición organizada por Fundación Cultural Mafre Vida, Madrid, 2003, pp.22 a 35.- J. SAN NiCOLÁs, "Regoyos (1857-1913) en Europa", Darío de Regoyos, Catálogo de la exposición organizada por Fundación Cultural Mafre Vida, Madrid, 2003, pp. 36 a 71.
Guiard, Ramón Casas, Santiago Rusiñol o Miguel Utrillo, les condujo a París.

A pesar de los esfuerzos de Ramón Martí Alsina (1826-1894) en Barcelona y de Carlos Haes (1829-1898) en Madrid, las artes contemporáneas españolas estaban sometidas al dictado de la jerarquía y de la tradición académica, y jaleadas por la crítica conformista.

Un año antes de que Regoyos viajase a Bruselas, en la Exposición Nacional de Bellas Artes de 1878, a la que concurrían pintores románticos como Vayreda, paisajistas que trabajaban sobre formatos medianos o pequeños como Carlos Haes y Aureliano de Beruete, la Medalla de Honor fue concedida a Francisco Pradilla por un cuadro de 5 metros de ancho por 3,50 metros de alto, con el tema Doña Juana la Loca cuyo texto literario se inspiró en la Historia de España de Lafuente. Otras obras presentadas mantenían en alto el estilo de vida moral y educativo derivado de los temas históricos, como Emilio Sala, con Guillén de Vinatea, delante de Alfonso IV haciéndole revocar el contrafuero, Casto Palencia, con Origen de la República Romana, y Salvador Martínez Cubells, con Educación del príncipe Juan. El contenido literario y ético, no exento de componentes escenográficos y teatrales, superaba con mucho al acto pictórico y creador ${ }^{2}$.

La historia seguía siendo el asunto estrella de la pintura española cuatro años después; en la Exposición Nacional de Bellas Artes de 1881, a la que concurrieron Joaquín Sorolla, Eliseo Meifrén, Cecilio Pla, Casimiro Sainz e Ignacio Pinazo, entre otros, el jurado otorgó la Medalla de Honor al arquitecto Juan de Madrazo y Kuntz por los proyectos historicistas para la restauración de las catedrales de León y Oviedo. Las obras fueron resueltas conforme a los

\footnotetext{
${ }^{2}$ B. DE PANTORBA, Historia de las Exposiciones de Bellas Artes, Madrid, 1980, p. 108 a 116.
} 
criterios de Viollet-le-Duc; los proyectos pretendían la restauración del esplendor gótico y la eliminación de las historias añadidas al edificio desde el siglo XIII, para buscar la historia legendaria y rutilante, escrita y exaltada por los poetas del siglo XIX.

El criterio de los responsables de las artes hispanas que se mantuvo hasta entrado el siglo XX, quedó reflejado en el siguiente hecho: Ignacio Zuloaga había expuesto sus obras en Bruselas con tanto éxito que las había vendido todas; paradójicamente, semanas después el jurado de una exposición oficial en España, rechazó la obra aportada por el pintor. Regoyos le escribió en los siguiente términos: "debemos felicitarnos de ser rechazados por estos señores /.../ toda España es una inmensa Batueca y por eso debemos tomar todo lo bueno de ella, los tipos, los pueblos, los montes, pero nunca entregar nuestras obras a ser juzgadas por un jurado de batuecos" ${ }^{\prime 3}$.

En 1890 concurrieron a la Exposición Nacional de Bellas Artes Darío de Regoyos con cinco obras y J. A. Mc Neill Whistler (1834-1903) con dos, el Retrato de Sarasate y Armonía en negro y gris. Retrato de la madre del artista ${ }^{4}$; todas ellas pasaron por el trance en medio del desinterés del jurado. "Armonía en gris y negro" $n^{\circ} .1$, con el retrato de Anna Mathilda Whistler, madre del pintor que a la sazón tenía 67 años, fue expuesto en la Royal Academy de Londres en 1872, en París en 1883 y en Madrid en 1890; un año después fue comprado por el Estado

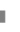

${ }^{3}$ J. I. TELLECHEA IdíGORAS, Darío de Regoyos, p. 43.

${ }^{4}$ B. DE PANTORBA, Historia de las Exposiciones..., p. 141, dice que el Retrato de la madre del artista, hoy en el Museo del Louvre, que estuvo situado sobre una puerta, recibió en El Imparcial los encendidos elogios de Jacinto Octavio Picón, que calificó la obra como "una magistral lección de sencillez".
}

francés para el Louvre (hoy depositado en el Museo d'Orsay) ${ }^{5}$.

Los considerados géneros menores, como el paisaje, el hombre y sus dramas, no tenían cabida en los salones oficiales y la tensión entre tradición e innovación, dialéctica de la que surgirán los factores renovadores de las artes, se estaba produciendo en las ciudades del Norte. Sirva de ejemplo el comentario de Narciso Sentenach; en 1895 había escrito la crítica de una exposición en la que participaba Regoyos en La Ilustración Española y Americana que comenzaba con las palabras: La neurosis nos ha invadido, y proseguía con una autentica diatriba contra "el llamado Impresionismo y otros defectos decadentistas transpirenaicos, han sido acogidos con carcajadas por nuestros sanos maestros, y apenas un secuaz han contado", en alusión directa al pintor riosellano ${ }^{6}$. Otro crítico, Cánovas, años después, tomaba a risa su Hora pálida y la tildaba de "mamarrachos emborronados" ${ }^{\prime \prime}$.

Es indudable que la pintura española estaba pasando por momentos difíciles desde principios del siglo XIX como consecuencia de distintos factores, que se verán

\footnotetext{
5 "Esta mala acogida le acompañó siempre en las Exposiciones formadas por jurados ineptos" (J. GUTIÉRREZ SOlANA, La España negra; Barcelona, 1972, p. 197).- J. A. GAYA NUÑO, La pintura española del medio siglo, Barcelona, 1952, p. 10, califica a Regoyos y Beruete de "lapiadados profetas de nuestra pintura". Véase también J. GUTIÉRREZ BuRÓN, "Artistas extranjeros en las Exposiciones Nacionales de Bellas Artes en el siglo XIX", Fragmentos, no. 15 y 16, (1989), pp. 37 a 57. Regoyos y su admirado Whistler se conocieron en el marco de una exposición de Los XX en 1884; posteriormente visitó al maestro en Londres. Muchos trabajos de Regoyos buscan sutiles armonías de luz, especialmente los efectos de luz nocturna.

${ }^{6}$ N. SENTENACH, La Ilustración Española y America$n a, \mathrm{n}^{\mathrm{o}} .25$, ( 8 de julio de 1895), p. 11

${ }^{7}$ A. CÁnovas, Diccionario Espasa-Calpe, t. L, p. 261 a 262. L. SANTOS TORROELlA, "Darío Regoyos", pp. 31, afirma que: "las críticas, como las de Antonio Cánovas, fueron perfectos exponentes de miopía, ligereza y vulgaridad".
} 
mitigados a fines del siglo, entre los que pueden citarse guerras civiles y coloniales más o menos larvadas, la incertidumbre de la economía nacional, la desconfianza de la política colonial, la desaparición del mecenazgo tradicional de la Iglesia y de la nobleza y el aislamiento de los procesos estéticos europeos como consecuencia del control ejercido, como en otros países europeos, por la Academia ${ }^{8}$. En relación con esta institución, aún sorprende al estudioso que el más incendiario de los discursos pronunciados contra la renovación de las artes proceda de Mariano Benlliure; en su discurso de ingreso en la Real Academia de Bellas Artes de San Fernando, el 6 de octubre de 1901, el escultor proclamó la necesidad de atajar de forma radical el rumbo de las artes, para concluir con una propuesta brutal: "es preciso aniquilar a todas esos desalmados antes de que ellos acaben con el arte".

\section{2. ¿POR QUÉ BRUSELAS?}

París, meta tradicional de artistas ávidos de novedades, aún era un foco cultural activo, pero Manet, que había consumado el estudio y análisis de la realidad desde los maestros del siglo XVII, expuso una obra paradigmática poco antes de su muerte en 1883, Un bar en el Folies-Bergère (1881); el cuadro podría calificarse como el gran epílogo de un sistema de representación creado a lo largo de la Edad Moderna que llegó agónico a los nuevos tiempos que nacieron de las Revoluciones Industriales.

El resto de los impresionistas interpretaban el mismo concierto, ya anticuado

\footnotetext{
${ }^{8}$ J. GUTIÉRREZ BuRÓN, “Artistas extranjeros en las Exposiciones Nacionales...", p. 37.

9 J. I. TELLECHEA Idígoras, Darío de Regoyos..., p. 112 a 118; Darío de Regoyos organizó una protesta firmada por el mayor número de pintores, especialmente vascos y catalanes, para "fastidiar a don Mariano el de la Española"(Ibidem, p. 98) -- M. J. QUESADA MARTín, “Cartas enviadas por Darío de Regoyos...", p. 245 a 273
}

y conservador, basado en los problemas derivados de la objetividad cromática del instante. El noruego Eduard Munch (18621944), generacionalmente muy cerca de Regoyos, rompió con esa neutralidad vital del impresionismo, para acercarse a la realidad de forma tan subjetiva que la mirada del pintor se hace cómplice del hombre y de sus vivencias del paisaje y de los objetos en tanto que reflejan momentos concretos del sentimiento del artista; en resumen, para mostrar el drama, las pasiones y lo insólito.

Para los artistas llamados a renovar la pintura París ya no era el centro de creación único y exclusivo. La nueva realidad que aparecía en las naciones industriales de Europa necesitaba formas de representación distintas a las derivadas de los siglos XVI y XVII, capaces de simplificar las composiciones $\mathrm{y}$, paralelamente, incrementar el papel expresivo del color, para comunicar plásticamente ideas complejas.

En efecto, algunos pintores de la generación de Darío de Regoyos no consideraron el ambiente parisino capaz de inducir a la modernidad. El momento que puede servir de referencia es 1879 , que corresponde a la llegada de Darío de Regoyos a Bruselas. Desde esa fecha Degas y alguno de sus seguidores como Mary Cassat, se apartaban del grupo impresionista como había hecho diez años antes Paul Cézanne que regresó a Aix-en-Provence, a la sombra de la montaña Sainte-Victoire, en donde buscó formas y colores estables y permanentes, clásicos en el fondo, para hacer obras que pudiesen ser expuestas en los museos; Paul Gauguin se había instalado en la pensión "Gloance" en Pont-Avent (Bretaña) y allí los jóvenes pintores como Serusier y los Nabis que peregrinaron en busca de una pintura cargada de contenido poético y simbólico hallaron formulas renovadoras; Vincent van Gogh aún no había llegado ni a París, ni a Arles, y Signac huía en su embarcación hacia las costas atlánticas. 
En París tan solo se movían como pez en el agua Henry de Toulouse Lautrec, y pintores extranjeros, entre ellos españoles, que buscaban la musa y el triunfo en la vida bohemia. Junto a todos ellos, los administradores y gestores de salones oficiales y no oficiales, y galeristas. En este ámbito fue extraordinario el papel desarrollado desde 1870 por la galería de Durand-Ruel; por ejemplo, en 1885, el marchante pasó unos días en Bruselas y en el hotel exhibió obras de Degas, Monet y Renoir.

Viena todavía no era una meta; no era la ciudad transgresora y vanguardista que estallará en 1890. "Aquellos vieneses /que/ no sabian que eran tan importantes", según José María Valverde, aún no habían llegado al panorama cultural europeo ${ }^{10}$. Faltan aún dos décadas para que Gustav Mahler cierre un tiempo y otros, como Arnold Schönberg, Adolph Loos, y Gustaf Klimt, cambien el sentido de las formas. El preludio lo escribieron Otto Wagner, en 1897, con Karlsplatz Stadtbahn Station de Viena y Joseph M. Olbrich, en 1898, con la Haus der Wiener Sezesión.

El hecho de que Carlos Haes, nacido en Bruselas, pero afincado desde los diez años en Málaga y posteriormente en Madrid, haya sido el profesor de paisaje de Regoyos en la Real Academia de Bellas Artes de San Fernando, no parece razón suficiente a algunos historiadores para justificar el viaje a Bruselas ${ }^{11}$. Pero si se considera que ambos en la capital flamenca, Haes entre 1850 y 1855, y Regoyos en 1879

${ }^{10}$ J. CASALS, Afinidades vienesas. Sujeto, lenguaje, arte, Barcelona, 2003, es una obra esencial para comprender la complejidad y riqueza del proceso cultural que se abrió en Viena a fines del siglo XIX. A. PIZZA Y M. PLA, Viena-Berlín. Teoría, arte y arquitectura entre los siglos XIX y XX, Barcelona, 2002, pp. 19 y 32

${ }^{11} \mathrm{~J}$. BLOCK, "Los XX: "los protadores de lo nuevo" y el nacimiento del arte moderno en Bélgica", en Los XX. El nacimiento de la pintura moderna en Bélgica, pp. 55 a 89
}

recibieron clases de Joseph Quinaux (18221895), un paisajista tardorromántico, de suave realismo a lo Millet y Menzel, que buscaba los efectos más poéticos de la naturaleza, no parece desechable esa idea inicial.

Haes que había expuesto en Bruselas en 1863 con un éxito tan notable que vendió todas los cuadros de la exposición, pudo contagiar a Regoyos y Beruete su educación cosmopolita y su admiración por el paisaje. No obstante, la formación de Regoyos se mantiene en una confusa zona de nadie como consecuencia de una afirmación del propio pintor en la que negaba el magisterio de Haes ${ }^{12}$. Hay veces que es necesario ponderar, con rigor metodológico, los datos que ofrecen los propios pintores. Si Quinaux le enseñó a enfrascarse en la naturaleza en 1879, es evidente que, unos años antes, Carlos Haes, profesor de paisaje e indudablemente un hombre curioso y cosmopolita, dejaría algún poso en la concepción del paisaje, en la infinita curiosidad por estudiar creadores y tendencias en las artes contemporáneas y en el cosmopolitismo de Regoyos.

\footnotetext{
${ }^{12}$ J. SAN NiCOLÁS, Darío de Regoyos- I, p. 20, y J. SAN NiCOLÁs, "Regoyos (1857-1913) en Europa", p. 38, cita como maestros de Regoyos a Van Sevendonck, Portaels y Quinaux y excluye a C. Haes porque el pintor escribió una carta a su amigo Paul Lafond, director del Museo de Pau, en la que negaba el magisterio del profesor de Bellas Artes. Resulta sorprendente la afirmación de Regoyos; Van Savendonck es un pintor hoy casi desconocido en Bélgica y la pintura de Portales y Quinaux está muy lejos de las propuestas del pintor asturiano; Jean François Portaels (1818-1895) es un curioso pintor romántico que cultiva diversos géneros, desde la pintura de historia a la religiosa, pasando por evocaciones exóticas, y Joseph Quinaux (c. 1822-c. 1895), que fue maestro de un gran número de pintores como: Willem Delsaux (1862-1945), Oswald Poreau (1877-1955), y los ya citados Carlos Haes, en torno a 1855, y Darío de Regoyos, conecta mas con la Escuela de Barbizon que con la obra de Regoyos. Véase también V. BOZAL, Pintura y escultura españolas del siglo XX, Madrid, 1992, p. 52.
} 
Bélgica, a la llegada del joven pintor español, era reino independiente desde 1831 de importancia excepcional entre las naciones industriales del mundo gracias a las inmensas riquezas que procedían del Congo, la finca personal del rey Leopoldo II, implacable explotador de los recursos humanos y naturales hasta inspirar uno de los personajes más negros de la literatura de la mano de Joseph Conrad. A esa Bélgica próspera y burguesa llegó Darío de Rego$\operatorname{yos}^{13}$; en un principio el objetivo del viaje era el de acompañar a sus amigos Isaac Albéniz que pensionado por Alfonso XII, en el Real Conservatorio de Música de Bruselas, había ganado el "Primer Premio con Gran Distinción" y al violinista Enrique Fernández Arbós que también había estudiado en el conservatorio de Bruselas y estaba llamado a dirigir las orquestas de New York, San Luis y Cleveland; en esta ocasión el músico recibiría el premio "Excelencia y capacidad", distinción raramente concedida.

Regoyos fue recibido por un país con una industria, un comercio y una economía excepcional, con inusitadas actividades políticas en el que florecieron movimientos anarquistas y socialistas; un pueblo con una prodigiosa actividad cultural como refleja la presencia de Albéniz y Fernández Arbós en el caso de la música; en literatura destacan Emil Verhaeren y Maurice Maeterlinck que con su Pelléas y Mélisande (1892), un drama de amor, conmovieron Europa e inspiraron composiciones incidentales de gran repercusión en la música contemporánea, como las de C. Debussy, Fauré, A. Schönberg y Sibelius; y, finalmente, pintores belgas como Constantin Meunier, Guillaume Vogels, Ferdinand Khnopff, James

\footnotetext{
${ }^{13}$ S. GOYENS DE HEUSCH, "El ambiente estético en Bélgica al advenimiento de Los XX", en Los XX. El nacimiento de la pintura moderna en Bélgica, Madrid, 2001, pp. 19 a 54
}

Ensor, o Théo van Rysselberghe, entre otros muchos.

Éste fue el excepcional marco cultural creado por el círculo de amigos de Darío de Regoyos en Bruselas, los que condujeron la cultura belga hacia la contemporaneidad. Los estandartes podrían ser el cuadro de James Ensor, La entrada de Cristo en Bruselas, de 1888, la Casa Tassel, proyectada por Victor Horta en 1890, prólogo de la transformación de la nueva arquitectura, y la obra de Henry van de Velde, apóstol entre los años 1900 y 1914 del nuevo arte (Art nouveau) en Alemania, en donde dejó el excepcional edificio de Weimar; Van de Velde fue uno de los renovadores de las artes industriales y del diseño, como quedó reflejado en su propia casa Bloemenwerf (1897), en Uccle, cerca de Bruselas.

El programa de las artes figurativas belgas tuvo un fuerte componente corporativo. En 1876 fue fundado el colectivo l'Essor, "impulso", que rechazaba de forma colectiva un altisonante neoclasicismo para profundizar en los problemas de la realidad; estaba animado por un grupo heterogéneo de pintores como Braekeleer desde una estética muy tradicional y el mayor de los llamados a ser veintistas C. Meunier que más tarde se convertiría en una de los más prestigiosos escultores de principios del siglo XX, con una obra que exaltaba el trabajo del obrero (Láms. 1 y 2). Darío de Regoyos participó activamente en los trabajos del grupo y su nombre figuró en el catálogo de la exposición de 1882-83. Por ese tiempo, Théo van Rysselberghe hizo un curioso y divertido retrato del riosellano tocando la guitarra.

En 1884, quizá como consecuencia del conservadurismo de l'Essor, abandonaron el grupo alguno de los pintores para formar Les XX, en cuyos folletos figuraban los nombre de Pantazis, Ensor, Vaugels, Khnopff, Van de Velde, Van Rysselberghe y 
Regoyos. Fueron miembros muy activos los abogados Edmond Picard y Octave Maus que habían fundado en 1881 la revista L'Art moderne, revue critique des Arts et de la Littérature, llamada a ser el órgano de expresión del nuevo grupo; desde ella los veintistas defendieron las propuestas de renovación en la literatura, la música y el arte.

Entre los cometidos de Les XX figuraba el de organizar exposiciones anuales en lugares públicos como el Palacio de Bellas Artes de Bruselas, en las que cada asociado podía exponer seis obras que quedaban relacionadas en un catálogo; no tenía un carácter competitivo puesto que no existía jurado alguno. Paralelamente a la muestra, se desarrollaban ciclos de conferencias y conciertos en los que se interpretaban obras de músicos contemporáneos, como Gabriel Fauré, Tchaikovsky y Cesar Frank. A esas exposiciones podían ser invitados a pintores extranjeros, no parece el caso de Regoyos ya que era miembro de Les XX de pleno derecho; en la nómina de invitados figuran nombres tan prestigiosos como Denis, Gauguin, Luce, Monet, Berthe Morisot, Camille Pisarro, Redon, Renoir, Seurat, Whistler, Sysley y Toulouse-Lautrec, artistas de excepción en la transición de la pintura europea más allá del impresionismo.

En efecto, Les XX inspirándose en el impresionismo, buscaron trascender la pura objetividad de la mirada para descubrir la fuerza expresiva de las formas y del color. (Láms. 3 y 4 )

\section{LA SUPERACIÓN DEL IMPRESIO- NISMO}

A propósito de una exposición celebrada en la Galería Biosca (Madrid) titulada, "Maestros del impresionismo español", el prestigioso crítico de arte José María Moreno Galván escribió: "Una concepción académica del impresionismo negaría automáticamente la existencia de maestros impresionistas españoles, salvo, acaso, la excepción de Regoyos ${ }^{\prime \prime 14}$.

La hipótesis que podría plantearse consistiría en llevar hasta sus últimas consecuencias el juicio de Moreno Galván, basado en el estudio de la imagen y de la representación, para sacar a Darío de Regoyos del catálogo de pintores impresionis$\operatorname{tas}^{15}$.

La argumentación necesita previamente resolver un interrogante: ¿qué es la pintura? Pero, en realidad, eso no es una pregunta, es una empresa imposible. Entre los múltiples aspectos que entrarían a formar parte de esa utópica, y por consiguiente imposible definición, debe considerarse esta afirmación: pintura es la realización de una imagen del mundo, a veces insólita, que se produce en el curso de un proceso intelectual en el que se sintetizan conceptos gestados en la imaginación tras la observación de la naturaleza. La imagen se instala en la conciencia de una colectividad, en el marco de una acción cultural; finalmente, el pintor, el individuo, la somete a la tekné y la llena de significados. El efecto de ese proceso creador se manifiesta como una acción unificadora de informaciones en la que no se expone la realidad, sino aspectos de una realidad múltiple. Desde este punto de vista, las artes no son solo materia, técnica, texto literario, testimonio de culturas, formas de pensamiento, conocimiento $\mathrm{o}$ trasunto social; son algo más porque los elementos que configuran un proceso estético no son algo, sino que significan algo.

\footnotetext{
-

${ }^{14}$ J. M. MORENO GALVÁN, “El impresionismo español", Triunfo, ㄲo. . 311, (8 de mayo de 1968).

15 Es evidente que en muchas fases de su vida Regoyos estuvo muy próximo al impresionismo; desde su temprano La plaza del Palacio Real con nieve (1882) y numerosas obras realizadas en el País Vasco (Playa de Zurriola, de 1886, San Sebastián nevado y Ría de Bilbao, de 1895, hasta las versiones de Camino de los neveros, de 1911, el pintor hizo del impresionismo su fórmula expresiva.
} 
Las artes figurativas, en este sentido, podrían ser definidas de forma muy incompleta como un conjunto de códigos expresivos que explican la imagen del mundo en el tiempo.

En este marco teórico adquieren inusitado protagonismo dos conceptos: imagen /del mundo/ y representación/del mundo/ pues son cambiantes en tanto que los factores culturales tales como sociedad, historia, pensamiento, economía, religión, etcétera, se transforman y cambian en el transcurso del tiempo. Durante el siglo $\mathrm{XV}$, imagen y representación del mundo formuladas en las cortes reales, ducales o eclesiásticas europeas, sobresaturadas de afectación cortesana, no son las mismas que las surgidas en la Florencia humanista cuya estética se nutrió con el pensamiento neoplatónico, o las que desarrolló el imperio otomano, cara rigurosa y guerrera del Islam.

La imagen es la unidad significativa con la que se escribe el texto pictórico y la representación es el proceso intelectual, el código que ordena esas imágenes y, posteriormente el recurso técnico mediante el cual se presenta aquel aspecto del mundo que previamente ha sido contemplado.

La pintura impresionista constituyó uno de los capítulos finales de un sistema de representación que se inició durante el renacimiento y que, en el marco de un proceso evolutivo, se diluye con las transformaciones de un ciclo histórico que anuncian las Revoluciones Industriales de la segunda mitad del siglo XIX y la quiebra de una urdimbre estética promovida por las nuevas teorías de las vanguardias históricas.

El impresionismo, como concepto pictórico que deriva de los intereses comunes de unos pintores, es un movimiento efímero. Entre 1860 y 1867 tomaron contacto una serie de pintores que trabajaban sobre un sistema de representación basado en la observación de la naturaleza; aunaban las experiencias de Gustave Courbet (18191877), Eugène Boudin (1824-1898) y del holandés Johann Barthold Jongkind (18191891), o de maestros más poéticos como Camille Corot (1796-1875), Charles F. Daubigny (1817-1878) o el británico Ch. P. Bonington (1802-1828), los pintores plein air.

En la década de los ochenta del siglo XIX los viejos modelos estéticos fueron discutidos desde distintos frentes y de forma tan radical que produjeron una crisis en las artes (arquitectura, pintura, escultura y artes suntuarias), sin precedente en los últimos cuatro siglos. Repartidos por Francia, en Bélgica y, posteriormente, en la Europa central emergen los superadores del impresionismo como Georges Seurat y Paul Signac y renovadores de las corrientes expresivas de principios del siglo XIX como Vincent van Gogh y Paul Gauguin ${ }^{16}$.

El proceso de representación del mundo que pusieron en práctica los pintores impresionistas tenía tras de sí un largo horizonte cronológico que arrancaba del renacimiento; la representación estaba regida por un sistema en el que los creadores conjugaban líneas, colores, volúmenes y espacios, mediante la perspectiva, la proporción y la armonía, tratando de descubrir el orden oculto de la naturaleza en un instante determinado.

La imagen, sin embargo, está sujeta a otras poéticas; el pintor del renacimiento ha tratado de recomponer la imagen ordenada y armónica del universo inspirada en la antigüedad clásica, mientras que el pintor barroco estudió la realidad y la naturaleza

\footnotetext{
16 "Si la realidad es uno de los elementos materiales del artista, el arte no puede reducirse a sus elementos reales"(E. LAFUENTE FERRARI, Ortega y las artes visuales, Madrid, 1970, p. 30).- "La visión del impresionismo que realiza Regoyos no es ya, sin embargo, una visión simple; es una revisión; esto es: la elección de una perspectiva que coincide con la misma línea del postimpresionismo" (F. CALVO SERRALlER, “Darío de Regoyos”, p. 19).
} 
para construir la imagen del mundo. La imagen bajo el sistema impresionista, es fundamentalmente visual, quizá también musical, pero esta cuestión momentáneamente queda al margen. La imagen impresionista se manifiesta por la existencia de la luz. Sin embargo, si en el Nacimiento de Ve$n u s$, de Sandro Botticelli, se hace de noche, o en los bodegones de Francisco Zurbarán se apaga la bujía que los ilumina, las imágenes permanecen, son eternas; la luz se limita a hacer visibles los objetos, las personas o los paisajes que existen, que están en un espacio accidentalmente sin luz. Por el contrario, en la pintura impresionista las imágenes son efímeras, viven en la medida en la que la luz las dota de forma y de color. La necesidad de hacer permanentes las imágenes hizo que Claude Monet pintase varias catedrales de Rouen entre 1892 y 1894, como fórmula para la superación del instante; la síntesis de las series haría objetivable la correlación imagen en función del tiempo (amanecer, mediodía, atardecer), de la luz (a pleno sol-sombra y todas las variantes) y el color. La luz en la pintura de Regoyos es un valor tan determinante como las formas, los colores, los volúmenes, los espacios y el peso de las figuras.

Las catedrales de Burgos que pintó en torno a 1906, como antes había pintado diversas Playa del Gros (1902), no son, como en el caso de Monet, variaciones objetivas de formas, colores y tiempo sobre la catedral de Rouen ${ }^{17}$; Regoyos pintó las distintas catedrales de Burgos, según los diferentes textos pictóricos que surgieron de una

\footnotetext{
${ }^{17}$ El propio Regoyos se justifica innecesariamente en una carta a Manuel Losada, fechada en otoño de 1906: "van a decir algunos que está iniciado por las Catedrales de Monet pero no tiene nada que ver una luz ni un país con otro y aunque uno hubiera visto las de Rouen yo hubiera hecho la de Burgos que desde niño he deseado pintarla"(J. I. TELLECHEA IDÍGORAS, Cartas..., p. 268).
}

aproximación afectiva al edificio ${ }^{18}$. Como los pintores de su generación, fue más allá de la mera objetividad impresionista para adentrarse decididamente en los territorios de la expresión simbólica del mundo. Transforma la realidad en una metáfora ${ }^{19}$. (Láms. 5 y 6)

En la pintura del riosellano, paradójicamente, la pincelada impresionista representa lo inconmovible de la naturaleza. En la representación y en la imagen, aludidas más arriba, hay poco de impresionismo y, en sentido inverso, mucho estudio de la pintura española del siglo XVII conservada en el Museo del Prado, una singular revisión de la pintura del siglo XVIII en el Louvre, y un gran conocimiento de veintistas y allegados como Whistler, Ensor, Khnopff, Signac, Gauguin, Degas, etcétera ${ }^{20}$.

Independientemente de los estereotipos con los que críticos contemporáneos pretendieron definir a Regoyos, tales como hombre sencillo, franciscano, infantil, inocente, geórgico que pintaba una col de rodillas, etcétera, Miguel Utrillo en su citado trabajo "Arte nuevo" dio la clave para situarle en la historia de la pintura: "la insaciable curiosidad que mueve el espíritu de Regoyos". Esa insaciable curiosidad; es la que le induce a superar el impresionismo; es la que le lleva frecuentemente a las capitales europeas, como Londres, París y Bruselas, para ver exposiciones, tal como queda de manifiesto en su correspondencia. Las pasea, las estudia, especialmente las de

\footnotetext{
18 Juan Gris afirmó: "Para que una emoción pueda ser transcrita en la pintura debe ser, ante todo, compuesta por elementos que pertenezcan a un sistema de estética resultante de la época", (citado por J. ROMERO BREST, La pintura europea contemporánea (1900-1950), México, 1952, p. 8).

${ }^{19}$ E. LAFUENTE FERRARI, Ortega y las artes visuales, p. 41.

${ }^{20}$ E. LAFUENTE FERRARI, Breve historia de la pintura española, Madrid, 1987, p. 521, empleaba una bella expresión para hablar de la naturaleza que le atraía: paisajes llenos de alma.
} 
Degas y la obra de Manet, y hace croquis de aquellas composiciones que le interesan que más tarde comparte con sus amigos. En una carta que remite a Théo van Rysselberghe aparecen apuntes de obras intimistas de Degas, en las que capta espacios entrañables de la mujer bañándose o vistién$\operatorname{dose}^{21}$.

La obra de Regoyos no debe ser estudiada a través de una fragmentada subdivisión en etapas; no hay cambios de método en su pintura; sí de concepto. Observa el mundo con una mirada regenaracionista, en la que dominan los aspectos de la realidad vistos bajo una óptica intimista, presentes en gran parte de su obra, y aspectos de la realidad bajo una óptica expresiva $y$, a veces crítica, dominada por el espíritu de España negra, que es dominante en su pintura al menos hasta 1900.

Su visión intimista de la realidad no constituye un mero registro espontáneo de sensaciones momentáneas, es la plasmación nostálgica de un sacralizado aspecto de la naturaleza (Pino de Béjar, 1900), el recuerdo de una intemporal y perezosa mañana en un puerto septentrional (Las redes, 1893), o el robo de un momento de intimidad con la naturaleza (Baño en Rentería de 1899, El gallinero, o Recogiendo fresas, de 1912). La pincelada puntillista no es la simple expresión teórica de una técnica, es el sistema que le permitirá captar y unificar todos los rincones poéticos de la naturaleza en una sola escena ${ }^{22}$. (Láms. 7 y 8)

La combinación de un suave realismo con la figura humana, preferentemente femenina, en su espacio, generadora de una atmósfera peculiar, fue una constante en la

${ }^{21}$ J. SAN Nicolás, Darío de Regoyos - I, p.106

${ }^{22}$ E. LAFUENTE FERRARI, “El paisaje en España”, en Un siglo de arte español, 1856-1956, Madrid, 1955, p. 35.C. REYero y M. FreiXA, Pintura y escultura en España, 1800-1910, Madrid, 1995, p. 303 pintura de los veintistas y allegados que adelantaron composiciones post-impresionistas francesas de principios del siglo $X^{23}$. Regoyos se comportó como un pintor intimista en la medida en la que trabajó sobre figuras casi siempre femeninas que realizaban placenteras labores domésticas. El pintor las contemplaba con una cálida y afectiva mirada, y las situaba en confortables espacios interiores tamizados por una luz, artificial que, con frecuencia, disolvía las formas para plasmar la atmósfera que emanaba del protagonista de la escena ${ }^{24}$. (Láms. 9 y 10)

\section{ESPAÑA NEGRA.}

En marzo de 1888, Darío de Regoyos escribió a Emil Verhaeren una carta de pésame por la muerte de su padre, y le invitaba a venir a España ${ }^{25}$. Aceptada la invitación, el poeta y el pintor hicieron un viaje a la búsqueda de un país bárbaro, atrasado y atávico; y lo encontraron jalonado por

-

${ }^{23}$ Sirva a modo de ejemplo los trabajos de J. Ensor, L'Après- midi á Ostende, 1881, La comedora de ostras, 1882. F. Knopff, Escuchando a Schumann, 1883, Gabrielle Braun, 1886, y Mlle. Van der Hecht, 1893. De Braekeleer, Le repas, 1885.- G. van Strydonk, Mujer en un interior, 1886.- J. Toroop, La dama de la sombrilla, 1888.- G. Lemmen, Joven cosiendo, 1887, Señora de visita, 1889 y La siesta, 1906.- A. Guillaumin, Lectura de una carta.- Théo van Rysselberghe, Mme. Van de Velde-Sethe, 1891, La dama de blanco, 1904.- Rik Wouters, Fleurs d'anniversaire y La repasseuse, 1912.

${ }^{24}$ Emma Bogaerts, (1883, colección privada).- La costurera, (1884, col. priv.).- Dama ante el espejo, (1885, en 1971 en la col. Regoyos).- Dolores Otaño, (1892, Museo del Prado).- Esposa de Regoyos cosiendo, (ca. 1892, colección privada).- Dos niñas haciendo encaje de bolillos, (1895, en 1971, col. Regoyos).- Amalia, (1899, col privada).- Desayuno de sus sobrinos, (1899, colección privada).- Isabel Regoyos, (1908, Casa Museo del pintor Abelló, Mollet del Vallés).- Encaje de bolillos, (ca. 1906, col. Regoyos en 1971).- Polluelos, (1912, Abadía de Montserrat).- Cogiendo fresas, (1912, col. Regoyos en 1971).

${ }^{25}$ Deseo expresar mi agradecimiento al doctor don Fernando Galván Freire que con paciencia y generosidad científica me facilitó los ejemplares de la revista L'Art Moderne. 
grandes iglesias como fortalezas y sombríos cementerios que dominaban los paisajes, con tipos sometidos por devociones milenarias y festejos basados en sangrientas corridas de toros e interminables noches gitanas a la vuelta de cada esquina.

Primero viajaron en diligencia; acompañados por el estruendo de los cascos, el crujido de hierros, el chasquido del látigo y las voces del mayoral, recorrieron la costa de Guipúzcoa; partieron de San Sebastián y visitaron Guetaria, Zarauz y Rentería; posteriormente, en ferrocarril llegaron a Pamplona y siguieron hacia Madrid, El Escorial y Ávila, para concluir el viaje en Burgos.

La experiencia fue narrada por el poeta flamenco en las páginas de la revista L'Art Moderne, bajo el título genérico de "Impresions d'artiste" dedicadas a Darío de Regoyos $^{26}$. El poeta dio una visión tópica y anecdótica de España que oscilaba entre la admiración y la tristeza, y entre la alegría y el estereotipo.

Diez años después, en diciembre de 1898, en la revista $L u z$ fundada por Joseph M. Roviralta y Darío de Regoyos, las observaciones de Verhaeren aparecieron publicada por entregas ${ }^{27}$. El pintor, con sus pro-

\footnotetext{
${ }^{26}$ L'Art Moderne, revista crítica de las artes y de la literatura, con un Comité de redacción formado por Octave Maus, Edmond Picard y Emile Vehaeren, con domicilio en rue de 1'Industrie, número 26, e Bruselas, publicó en 1888, "Impresions d'artiste. A Dario de Regoyos" en los números 25 (17 de julio), 28 (8 de julio), 30 (22 de junio), 32 (5 de agosto). Posteriormente, en 1901, en un nuevo viaje por España acompañado por su esposa Marta Massin y por Darío de Regoyos, visitan Pancorbo, Haro, Valladolid y Toledo y retoma el poeta la narración viajera (vid. EMILE VeHAEREN, "Impresión d'Espagne. La Fete de San Felice de Haro", L'Art Moderne, no. 31, (4 de aout, 1901), p. 261 y 262.

${ }^{27}$ En los números 8, 9 y 10 de la revista $L u z$, definida por un anticipado uso de palabras clave como: periódico, semanal, arte, moderno, y presididas por unas portadas abiertas al dibujo modernista y las poéticas aguadas al modo japonés.
}

pias notas y apuntes gráficos, había añadido nuevos textos y un conjunto de ilustraciones a esas iniciales "Impressions d'artiste" y las editó bajo el título, gestado al alimón por el riosellano y Rodrigo Soriano, de España negra.

El epígrafe que encabeza la primera entrega dice así: España negra por Emile Verharen. Traducción e ilustraciones de Darío de Regoyos. Cada uno de los capítulos fue titulado: I.- "Por la costa Cantábrica"; II.- "Aurresku de niños.- Fiesta de San Juan en Tolosa San Marcial en Vergara"; III.- "Impresión de verano en Guipúzcoa"; IV.- "San Fermín Chico en Pamplona"; V.- "Impresiones crepusculares.- Un café cantante en Zaragoza. Sigüenza. El Madrid de Verhaeren.- La funeraria.- El Museo del Prado.Una tarde en El Escorial. Conclusión". Acompaña al texto un conjunto de ilustraciones realizadas por Regoyos.

En 1899, la firma comercial Imprenta de Pedro Ortega, de la calle Aribau de Barcelona editaba el trabajo en forma de libro, con la inclusión de 27 grabados y 7 xilografías originales sobre plancha de boj ${ }^{28}$. Fue la primera versión en forma de libro de España negra que difería muy poco de la que el pintor asturiano había publicado por entregas en la revista $L u z^{29}$.

\footnotetext{
${ }^{28}$ M. L. DE LUXÁN Y M. VALDÉS, “Darío de Regoyos entre la crítica...", pp. 7 y 8.

${ }^{29}$ Las ilustraciones que aparecieron en las primeras dos ediciones eran: p. 9.- Mariscadoras en un pedral; p. 10.- Diligencia vascongada; p. 11.- Vieja guipuzcoana y San Antonio de Guetaria; p. 12 Gato sobre silla de anea y Tipo vascongado; p. 15.- Visita de pésame; p. 17.- Altares de Guipúzcoa; pp. 19 y 20.- Esculturas de Guipúzcoa (xilografía sobre madera de boj); p. 23.-Alguacil de Tolosa (xilografía sobre madera de boj); p. 23.- Alguacil de Tolosa (xilografía sobre madera de boj); p. 24.- Las Hijas de María en Gupúzcoa; p. 26.- Jesuita de Loyola; p. 29.- Baile en El Antiguo; p. 30.- Pescadores de Sardinas; p. 32.- Peregrinación en el Cabo Machichaco; p. 33.- Viático (xilografía sobre madera de boj); p. 35.- Penitente de Machichaco; p. 36.- Mendiga de Castilla; p. 40.- Viuda española; pp. 41 y 42.- Víctimas de la fiesta; p. 46.- Gitano;
} 
Entre las ediciones de "Impresions d'artiste" de 1888 y España negra, de 1898, existen tres matices que las hacen distintas. El primero deriva del título de la obra: España negra; en Verhaeren no hay tal cuestión; como mucho en el texto de L'Art moderne, cuando al poeta belga le asalta la duda sobre el color de España la resuelve con un artificio literario: "Verdaderamente es necesario poner delante del ojo un monóculo rosa para ver España en claro y alegre. España es, esencialmente, un país fúnebre. Su bandera debería ser en lágrima de plata"30.

La conclusión de que España es negra fue el fruto de una idea de Regoyos largamente debatida con sus amigos, Emil Verhaeren y Rodrigo Soriano. El propio Verhaeren en una semblanza que hace del pintor, dice: "Darío de Regoyos s'est évertué à nous peindre l'Espagne provintial, silencieuse et sombre. Il aimait à la nommer España negra, $c^{\prime}$ st-a-dir l'Espagne noir ${ }^{\prime \prime 31}$. Crisanto de Lasterra cuenta que: "en San Sebastián Regoyos había formulado a su amigo Soriano aquella curiosa pregunta: ¿España es negra o es azul?"32. La conclusión aún provisional es que nadie vio España tan negra como el pintor.

La redacción y la ilustración de España negra son una de las múltiples repercusiones del compromiso del intelectual con el mundo. Las observaciones de ambos

p. 47.- Claro de luna; p. 51.- Impresión de pescante (xilografía sobre madera de boj); p. 54.- Sacristán; p. 56.Cantaora y guitarrista; p. 57.- Ciego de viaje; p. 58.- Una calle de Sigüenza; p. 62.- El día de difuntos; p. 66.- Paisaje de El Escorial; p. 69.- Ávila con luna (xilografía sobre madera de boj); p. 71.- Campana; y p. 73.- La procesión de San Vicente (xilografía sobre madera de boj).

${ }^{30}$ E. VERHAEREN, “Impresions de ...", L'Art Moderne, no. 30, (1888), p.235.

${ }^{31}$ E. Verhaeren escribió este texto en el prólogo de la exposición del pintor en la Galería Choiseul (véase Los XX. El nacimiento de la pintura moderna en Bélgica, Madrid, 2001, p. 130).

32 "Darío de Regoyos poesía del color y de la luz", En París con Paco Durrio, Bilbao, 1966, p. 137. creadores están en consonancia con el papel renovador que pusieron en marcha los miembros de Los XX y del órgano de difusión de sus ideas, L'Art Moderne, ante las transformaciones radicales que se estaban produciendo en la Europa de las revoluciones industriales introdujeron, desde el escultor C. Meunier, hasta el abogado E. Picard, desde Regoyos hasta P. Signac; quizá no sea aun, académicamente, el tiempo de las vanguardias, pero Les $X X$, y los redactores de L'Art Moderne y de La Libre Esthétique buscaron denodadamente propuestas críticas y estéticas vanguardistas ${ }^{33}$.

Muchos conceptos estéticos ya estaban definidos con anterioridad a 1888. Las propuestas de carácter expresivo, similares a las vertidas en las ilustraciones textuales o pictóricas de España negra, ya están obras realizadas por nuestro pintor en Bélgica, como "El mes de María en Bruselas", de 1884, o "Noche de difuntos" expuesta en el IV Salón de Los XX, Bruselas, 1885, o en España, como la "Diligencia de Segovia", de 1882, o Mendigos I y II, pintados en 1882.

Los recursos expresivos y la temática que refleja España negra, fueron dominantes en la pintura de Regoyos; la mirada, casi siempre crítica, que el pintor tendía sobre las creencias religiosas fue constante durante la década de los años $90^{34}$. Una lectura

\footnotetext{
${ }^{33}$ Edmond Picard, copropietario de L'Art Moderne, abogado y político socialista, mostró una permanente atracción por la vanguardia, proponiéndola como objetivo permanente de la pura crítica (E. PICARD, L'Art moderne, 4 de janvier, 1891, p. 3 y 4). Picard, en 1884, en las páginas de su revista, se proclamó con los veintistas "croyants de l'Art nouveau". Años después, en 1900, E. VERHAEREN, "Art nouveau”, en La Libre Esthétique, nº. 15, abril, págs 119 y 120, retomaba la exaltación de las vanguardias y del art nouveau. Sobre este tema véase también R. SCHMUTZLER, Art nouveau, New York, 1962, pp. 124 y 125; R. VERVLIET, "Lever le rideau: les précurseurs", en Les avant-gardes littérairies en Belgique, Bruxelles, 1991, pp. 27 a 90.

${ }^{34}$ En la iglesia y Procesión en Rentería, de 1890; El paseo, La creyente, Las Hijas de María, Mirando la proce-
} 
detenida de España negra induce a resaltar la importancia como escritor de Regoyos; las dificultades de atribución derivan de la unidad de espíritu con la que ambos iniciaron el viaje ${ }^{35}$; compartieron el mismo empeño: "ver el mundo del modo más desapacible y tétrico". Indudablemente el pintor asumió la actitud hipercrítica del poeta.

El estudio de un dibujo de Regoyos denominado "Aragonés" puede servir de ejemplo que ilustre sobre la participación del pintor en la redacción de España negra y la coincidencia con el pensamiento de la generación del $98^{36}$. Es un apunte rápido, enérgico y certero de un tipo popular netamente hispánico; en el reverso escribió: "España salvaje porque el clima y las posadas la hacen insoportable, las chinches, el ajo, la pimienta, las salsas, aceite, el pan, el vino, la suciedad en todo, y los perros que ladran de noche $y$ los gallos que no dejan dormir, los caminos que no son más que pedruscos..." ${ }^{137}$. Juicios y

sión, de 1891; Visita de pésame, de 1894, El monasterio, de 1895, Madrugada de Viernes Santo, de 1903, Viernes Santo en Castilla, de 1904 y Procesión de capuchinos. Fuenterrabía, de 1908. En 1888, fecha del viaje de Verhaeren y Regoyos, James Ensor (1860-1949) dio por concluido "La entrada de Cristo en Bruselas" (Museo Voor Schone Kunsten), su irónico manifiesto sobre la adaptación de la idea religiosa a los nuevos tiempos.

${ }^{35}$ E. Verhaeren, "Darío de Regoyos", en Darío de Regoyos 1857-1913, pp. 46 a 47.- J. TUSELL, “Darío de Regoyos y la introducción ...", p. 15

${ }^{36}$ En relación con esa visión de España deben citarse los Dibujos coloreados de temas españoles, realizados entre 1888 y 1892; Novillos en Rentería. Tiempo gris, de 1890, y sobre todo Victimas de la fiesta, de 1894 y la colección de 15 litografía que componían el Álbum basco, de 1897. Sobre los aspectos literarios de la obra de Regoyos, véase E. LAFUENTE FERRARI, "Pintura española y generación del 98", Arbor, nº. 36, (1948), pp. 449 a 458.- M. L. DE LUXÁN RODRÍGUEZ Y M. VALDÉS FERNÁNDEZ, "Darío de Regoyos entre la crítica y la literatura ...", pp. 3 a 17.- M. C. PENA, Pintura de paisaje e ideología. La Generación del 98, Madrid, 1982.- M. VALDIVIELSO, “El paisatge com evasió en els escriptors de la generació del '98 i la pintura de Darío de Regoyos", Revista de Cataluña, no․ 45, (1990), pp. 87 a 103.

${ }^{37}$ M. VALDÉS FERNÁNDEZ, “Un dibujo negro de Darío de Regoyos", Anales de Historia del Arte. Homena- estilo literario son muy similares a los vertidos en España negra y son, igualmente, los que inducen al estudioso a formular una hipótesis de trabajo: Darío de Regoyos desempeñó en la empresa editorial el cometido del ilustrador y, circunstancialmente, el de escritor ${ }^{38}$.

No coincide en muchos aspectos "Impresions d'artiste" y España negra; capítulos como "III.- Impresiones de verano en Guipúzcoa" hay textos nuevos que no aparecen en L'Art moderne; el citado capítulo constituye un casi permanente discurso del pintor, desde las descripciones cromáticas de un paisaje, hasta el comentario de escenas de carácter costumbrista. Sirva de ejemplo de ambas afirmaciones el texto que describe, en primer lugar el camino entre Guipúzcoa y Navarra: "para pintar aquellos campos parece que hace falta una nota de luz que sirva de dominante como el último rayo de sol rojizo o anaranjado que forme sus complementarios u oposiciones azules..." ${ }^{39}$; mientras que en la costa guipuzcoana describe un momento holgazán en un puerto pesquero: "Allí hay marinas que vistas al través de las redes puestas a secar forman telones extraños como cuadros de pintura pointillée ó puntista", texto que es la perfecta descripción de una de las obras maestras del pintor: Las redes, de 1893 (colección privada), tela que expuso

je al Profesor Dr. D. José María Azcárate Ristori, $\mathrm{n}^{-}$4, (1993-1994), pp. 685 a 689. La técnica dibujística empleada por Regoyos coincide con obras realizadas entre 1888, como Ciego, (col. Alfonso Zorilla Lequerica, Bilbao) y 1892 como el retrato de Rodrigo Soriano y Mujeres gallegas (Museo de Arte de Cataluña). Por el contrario, la técnica está mas cerca del retrato de Emil Zola que la empleada en los dibujos que el pintor realizó en Zaragoza en 1884.

${ }^{38}$ C. DE LASTERRA, "Darío de Regoyos poesía del color...", p. 137, escribe: "/.../ con parte de aquellos artículos (el autor se refiere a "Impresions d'artiste" de Verhaeren), que el propio Regoyos tradujo, y añadiéndoles por su cuenta otros capítulos originales suyos publicó nuestro pintor, muchos años después, aquel conocido librito, hoy tan difícil de encontrar, titulado "España negra".

${ }^{39}$ España negra, 1899, p. 37. 
en el IX Salón de los Artistas Independientes de París $^{40}$. (Lám. 13)

La obra que puede sintetizar la constante visión crítica de una España negra es Víctimas de la fiesta ${ }^{41}$; la obra, que fue expuesta en el Salón "Libre Esthetique" de Bruselas, en 1895, inaugura recursos expresivos que explorarán los expresionistas germánicos en la segunda década del siglo XX y más tarde, entre 1934 y 1937, P. Picasso en sus tauromaquias, minotauromaquias y Guernica ${ }^{42}$. (Láms. 11 y 12)

A fines del siglo su vehemente visión se hará menos desgarrada; sin abandonar el expresionismo, el pintor desarrollará el estudio poético del color en función de un espacio sometido a situaciones extremas de luz natural y artificial; sus propuestas adelantan soluciones centroeuropeas de la primera década del siglo XX; sirva de ejemplo su Nocturno, de 1899 (col. privada) ${ }^{43}$. (Láms. 13 y 14)

\section{DARÍO DE REGOYOS: VARIOS RETRATOS Y UN AUTORRETRA- TO.}

Edmond Picard, en su revista L'Art Moderne, publicó en 1899, un retrato de

\footnotetext{
${ }^{40}$ España negra, 1899, p. 31.

${ }^{41}$ Existen dos versiones de esta obra; en sentido estricto son dos interpretaciones distintas de un mismo tema; en el grabado expuesto en la Casa Museo del pintor Abelló, en Mollet del Mar, Barcelona, el triste protagonista es el caballo, y en el lienzo, tratado con técnica mixta, óleo y pastel, de la colección Caja Astur de Oviedo, sobre un obsesivo paisaje de atardecer aparece el segundo protagonista de la matanza: el hombre.

${ }^{42}$ Sobre esta obra, escribió Octave Maus: "Je viens définir une toile que l'on ne peut pas exposer en Espagne à moins d'aller à l'échafaud, car ici l'on est complètement isolé et l'on a l'air d'un fou même parmi les peintres espagnols".

${ }^{43}$ Esta captación de un paisaje, casi siempre urbano, la repetirá años después, por ejemplo, Catedral de Burgos, atardecer, de1906, Calle de Granada, de 1910 y El paseo de Gracia de noche, 1912.
}

Darío de Regoyos que aquí se resume: No ha sido olvidado este compañero encantador, este pintor nervioso y original, este guitarrista siempre inquieto e incitador a la inquietud, este cantante ronco y seductor que os transportaba rápidamente a la ensoñación, este amigo sombrío y risueño, este hombre de mirada bizarra con la que evoca el África bárbara, en tanto que España, Navarra, Basconia. La memoria del espíritu y la memoria del corazón, le siguen fieles para tanta poesía que esparcía en torno a él durante las noches serenas en nuestros bosques, o durante los atardeceres de invierno en los salones íntimos, en la cordialidad de una atmósfera perfumada.

El crítico belga consideró la pintura de Regoyos de forma muy distinta a como lo hicieron los españoles, con las dignas excepciones de L. A. de Barán, seudónimo de Miguel Utrillo, Paul Lafond, director del Museo de Pau y el escritor Jacinto Octavio Picón ${ }^{44}$; en su opinión las obras de Regoyos están fuertemente impregnadas de su raro talento de pintor, donde ha encontrado un colorido jugoso, pleno de sentimiento, con excelente guiso de paleta que refleja su alma lánguida, ardiente y libre, el mismo que mueve su mano cuando maneja el ágil pincel o las cuerdas vibrantes de una guitarra. Picard concluía su retrato con un lamento: hoy se encuentra en un retiro modesto y laborioso más allá de los montes Pirineos, al pie de la cadena Cantábrica. Sus amigos de aquí, a quienes colmó antaño con sus tristes canciones, sus humoradas, sus dibujos y sus extraños bocetos, aún le recuerdan.

\footnotetext{
${ }^{44}$ L. A. DE BARÁN, "Arte nuevo. Darío de Regoyos", LUZ, no. 8, $1^{\text {a }}$ semana de 1898 ; en este número apareció la primera entrega de España negra.- P. LAFOND, "Darío de Regoyos", pp. 37 a 42. J. Octavio PICÓN, en La Ilustración Española y Americana, no. 25, (1897), p. 375.
} 
Octave Maus, coeditor de $L^{\prime}$ Art Moderne, crítico de arte y abogado belga, escribió un texto en homenaje a Darío de Regoyos al año de su muerte; le recordaba como un hombre pequeño, de tez oscura, barbudo, envuelto en una capa, animador de la vida bohemia, los cenáculos intelectuales y culturales de Bélgica con una guitarra que había apostado por una pintura de colores claros y brillantes de su país ${ }^{45}$.

En el frontispicio del catálogo de la exposición Darío de Regoyos 1857-1913, promovida por la Fundación Caja de Pensiones y celebrada en Madrid entre los meses de noviembre de 1986 y enero de 1987, se recoge la respuesta de Darío de Regoyos a una "Encuesta sobre las tendencias actuales en las artes plásticas", que había publicado Mercure de France en el año 1905: "Admiro toda la obra de Whistler, Gauguin y Cézanne. Los maestros antiguos cuya obra más me ha gustado son Sánchez Coello, Goya, Velázquez y El Greco. Pero he rehuido su exclusiva influencia porque me gusta mi época y porque quiero pertenecer a ella. Por lo tanto, adoro a Corot, Manet, Monet, Renoir y los impresionistas armonistas".

Sorprende que quien ama tan intensamente el impresionismo, de entre todos los pintores tan solo el nombre de Claude Monet responda estrictamente a un pintor impresionista; Corot contempla la realidad desde el equilibrio de un clásico, Renoir va por otros caminos y Manet, en sentido estricto, no es impresionista, es un pintor que a veces hace pintura impresionista. $Y$, por otro lado, los clásicos que cita el pintor riosellano están siempre en el librillo de los creadores.

Del conjunto de juicios que vierte en el Mercure de France la afirmación que alcanza un valor excepcional por lo que tiene

45 "Hommage a Darío de Regoyos", La libre Esthétique. $\mathrm{n}^{\mathrm{o}} .7$, mars, 13 avril 1914. de opción estética y compromiso personal y artístico es: "Admiro toda la obra de Whistler, Gauguin y Cézanne" ${ }^{\prime \prime 4}$; Gauguin y Cézanne, como ya se dijo, se apartan de forma decidida del impresionismo para tender una nueva mirada sobre la naturaleza para profundizar en nuevas posibilidades expresivas de los espacios, de las formas y de los colores, y Whistler buscó valores líricos cercanos a las propuestas art nouveau (Láms. 15 y 16). En alguna medida, la lánguida y poética mirada que Whistler extendía sobre el mundo, interesó a Regoyos quien, en 1885, hizo una visita a Londres para conocer al pintor americano (Lám. 17); de ese encuentro, además de una relación de amistad, nuestro pintor realizó algunos retratos del maestro y el dibujo para el proyecto de un cuadro sobre Londres que tenía la intención de titular Cheapside. La búsqueda de sutiles efectos de luces, de luna, atardeceres y ocasos, efectos de luz eléctri$\mathrm{ca}$, cargados de matices expresionistas o intenciones poéticas muy cercanas al modernismo siempre han estado presentes en la pintura de Regoyos ${ }^{47}$.

En el friso de este trabajo figura: "Si volviera a comenzar mi vida /me entregaría/ por completo a las impresiones que recibiera de la naturaleza". Regoyos no fue, en sentido

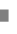

46 "J'admire dans leur oeuvre entiere Whistler, Gauguin et Cézanne" (Mercure de France, aout, 1905, pp. 552 y 553).

${ }^{47}$ En 1881 ya mostró esa preocupación en Molino de noche (Holanda), Effets de lumière, ambas obras están en colecciones particulares; entre 1882 y 1890 La playa de Almería (colección privada) y Noche de difuntos (en 1971, propiedad de las hermanas Regoyos) y Luz eléctrica. Aragón (Museo de Bellas Artes de Bilbao); en los años noventa pintó entre otros, Nocturnos en el puerto de San Sebastián, Luz de gas en Rouen, Nocturno y Claro de luna en Burgos (todos ellos en colecciones particulares); ya en el siglo XX Nocturno, Marina (colección privada), Fuegos de artificio (Museo Municipal San Telmo, San Sebastián), Catedral de Burgos. Amanecer, Hora azul, Catedral de Burgos por la mañana, Puerto de Ondarreta y Castillo de la Mota, todos ellos en colecciones privadas.
} 
estricto, un pintor plein air; contemplaba la realidad por medio del caballete, la hacía suya a través de observación, apuntes y bocetos como Cheapside, y posteriormente, asimilados todos los datos, la representaba según sus especulaciones expresivas y simbólicas derivadas de la síntesis naturaleza, figuras, luz, color (Lám. 18).

Ha sido uno de los pintores más retratados por sus colegas; un apunte de L. Rops, varios retratos de Théo van Rysselberghe, otros de Ensor, Meunier, Casas, etcétera, pero quizá el más comprometido con la nueva pintura sea su Autorretrato, de 1895 conservado en el Museo de Bellas Artes de Asturias (Lám. 19). Como hicieron otros pintores de su misma generación, profundizó en su propio rostro para buscar los principios del retrato contemporáneo; el pintor esculpió, más que pintó, lo que interpretaba como su imagen global sobre una ventana, cerrada en parte por lienzos colocados al revés, en la que se intuye un poético paisaje modernista ${ }^{48}$.

\footnotetext{
${ }^{48}$ Es un cuadro doble; en el reverso hay un paisaje que el propio pintor en un lateral de su retrato tituló Valmaseda. Antes, en 1879, se hizo un autorretrato que mandó a Théo van Rysselberghe (colección privada). Darío de Regoyos fue retratado por Théo van Rysselberghe, en 1882 (Museos Reales de Bélgica, Bruselas), Constantin Meunier, en 1884 (col.privada, Lausanne), James Ensor, 1884 (Col. Credit Comunal de Bélgica, Bruselas), Théo van Rysselberghe, en 1889 (colección privada), junto con Pichot, Ricard Opisso, en 1894, nuevamente Théo van Rysselberghe, 1896 (Museo del Prado, Casón del Buen Retiro), Ramón Casas y, finalmente, Vázquez Díaz sobre la fotografía de Regoyos que fue publicada en Cartilla de arte pictórico de Cecilio $\mathrm{Pla}$; muchos de los retratos, especialmente los del joven Regoyos, lo muestran cantando y tocando la guitarra. La plasmación del poético y sentimental color modernista lo experimentó en obras como Vieux chateau, de 1893, Playa de Gros (San Sebastián) y Atardecer (San Sebastián), de 1894, Puerto de Ondarroa, de 1907 y Castillo de la Mota, de 1909, entre otros cuadros.
}

\section{EPÍLOGO.}

En 1894, cuando ya era un pintor respetado por artistas españoles y críticos belgas, sus amigos catalanes, como Casas, Rusiñol, Gaudí, Pascó, Casellas, Sardá, Pellicer, Pichot, etcétera, compraron el cuadro Hijas de María (Bruselas), de 1884, de Darío de Regoyos, y lo donaron al Ayuntamiento de Barcelona, obra que, según J. Rafols, los ediles rechazaron para no desairar al jurado que una vez más había rechazado una obra de Regoyos ${ }^{49}$. Pero lo importante de este suceso es el reconocimiento de los pintores vascos, catalanes y madrileños de la personalidad artística del ya cansado trotamundos. No obstante mantenía su prestigio ante las galerías de París; la galería Durand-Ruel le propuso la organización de una exposición sobre la joven pintura española; la empresa fracasó por la confluencia de múltiples y contrarios intereses ${ }^{50}$.

Algo similar había pasado con los escritores del primer tercio del siglo XX; hicieron suyas las palabras de Pío Baroja: "Regoyos tenía nuestro color y nuestra actitud"; el color y la actitud de toda una generación de escritores españoles que se manifestaron literariamente en el desastroso marco político español de 1898. En 1921, ocho años después de su muerte, ofició Ramiro de Maeztu un homenaje al pintor promovido por los intelectuales españoles.

En el mercado del arte y en el coleccionismo tradicional la obra de Regoyos mantuvo una cotización estable, con un

\footnotetext{
49 A. L. DE BARÁN, “Arte nuevo",. Luz, Op cit. - J. F. RAFOLS, El arte modernista en Barcelona, Barcelona, 1943, p. 103.- F. FONTBONA, "Regoyos en Cataluña", p. 23.

${ }^{50}$ En la correspondencia de Regoyos correspondiente a los años 1902 y 1903, hay abundantes datos sobre las controvertidas exposiciones de la joven pintura española, o vasca, o catalana, en la galería Durand-Ruel o en la galería Silberberg, calificada ésta última por Regoyos como un lugar malísimo (I. TELLECHEA IDÍGORAS, Darío de Regoyos. Cartas..., pp. 118 y
} 136). 
crecimiento moderado como respuesta al escaso número de obras que circulaban. En torno a 1970, la familia Regoyos, en la que confluyeron las colecciones privadas del riosellano y de Aureliano de Beruete, sacó al mercado un número indeterminado de obras. El hecho tuvo un impacto sobre la cotización del pintor como consecuencia de un nuevo y ávido coleccionismo que despertó, a su vez, una inevitable desconfianza hacia las nuevas obras que salían al mercado, a la vez que entorpecía la musealización de sus cuadros, hoy dispersos por colecciones privadas ${ }^{51}$. De todas formas, recientes exposiciones que tuvieron como protagonista a Darío de Regoyos, como las organizadas por la Fundación Caja de Pensiones de 1987 y las de Fundación Cultural Mapfre
Vida de 2001 y 2003, colocaron al pintor riosellano en un lugar de excepción, aunque difuso, de la pintura contemporánea.

$\mathrm{Su}$ vida como hombre moderno, abierto a las grandes experiencias europeas, que "vivió en todas partes" como afirma atinadamente García Guatas, fue como un espléndido viaje por las transformaciones de la pintura europea de $1900^{52}$. Pero el trayecto concluyó en 1913, cuando, aceptada ya su enfermedad, un brutal y doloroso cáncer de lengua, escribió a Daniel Zuloaga: "Ya he dicho adiós a la vida no voy a ninguna parte" ${ }^{\prime \prime 53}$.

\footnotetext{
${ }^{51}$ No deja de sorprender que, por ejemplo, los óleos Día de difuntos y Las redes, y la acuarela Mujer contemplado el mar, obras de excepcional importancia para la historia de la pintura contemporánea, que en el año 1971 formaban parte de la colección Regoyos, hoy se expongan bajo el ambiguo enunciado de colección privada.
}

\footnotetext{
${ }^{52}$ M. GARCÍA GUATAS, "Paisajes con ferrocarril en la pintura de Regoyos", Goya, no. 299, marzo-abril, (2004), p. 115

${ }^{53}$ J. I. Tellechea Idígoras, Darío de Regoyos. Cartas..., p. 241 y 242.
} 


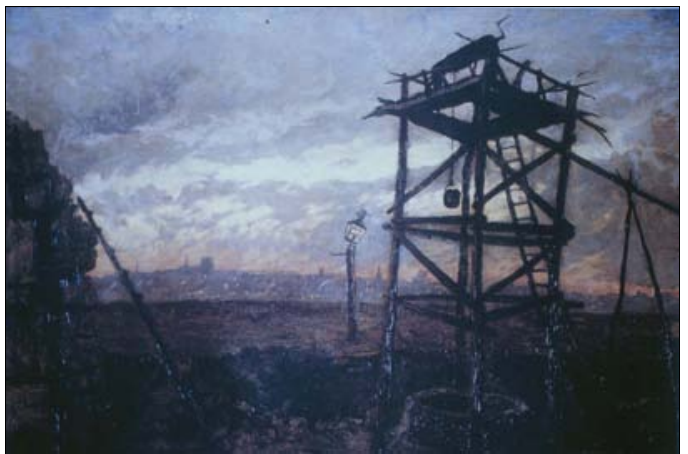

- Lám. 1. D. DE REgOYOS, 1881. Alrededores de Bruselas (colección privada)

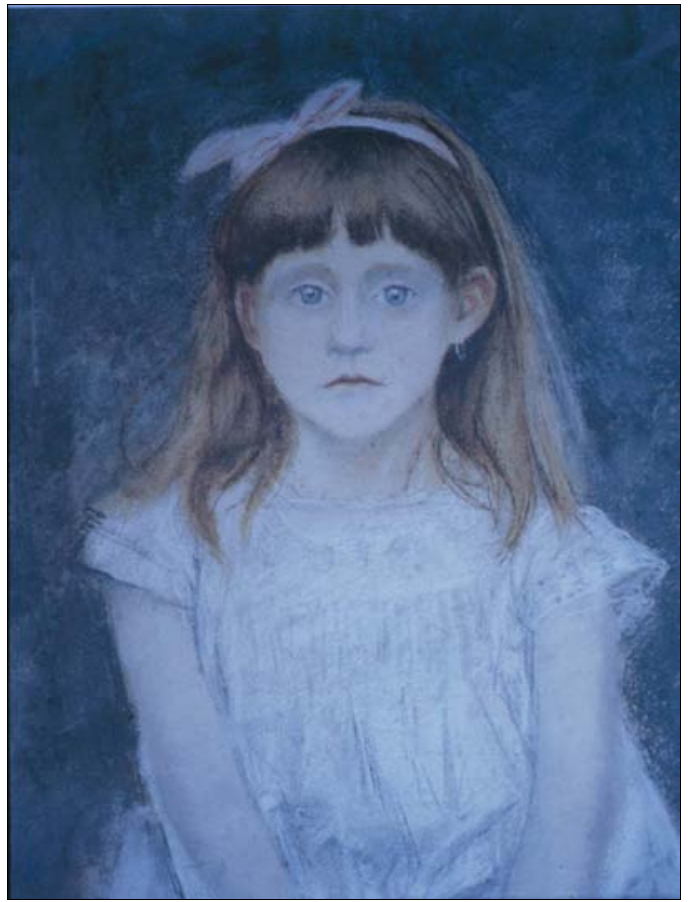

- Lám. 3. D. DE RegOYOS, 1883. Emma Bogaerts (colección privada)

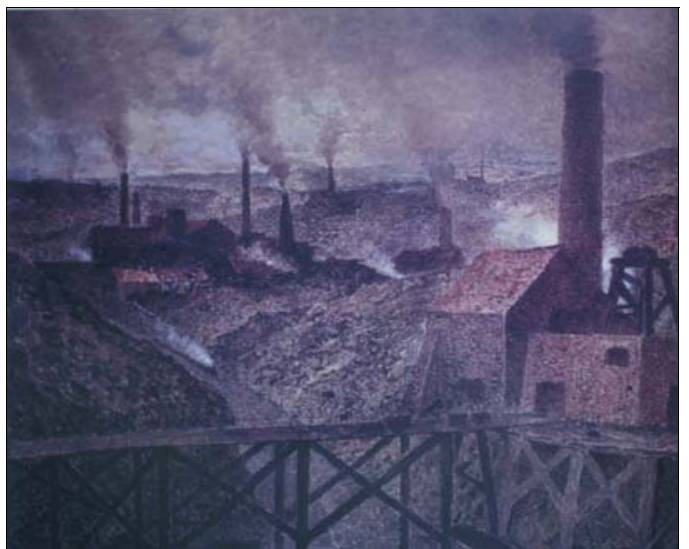

- Lám. 2. C. MEUNIER, 1893.- El país negro (Museo d'Orsay, París)

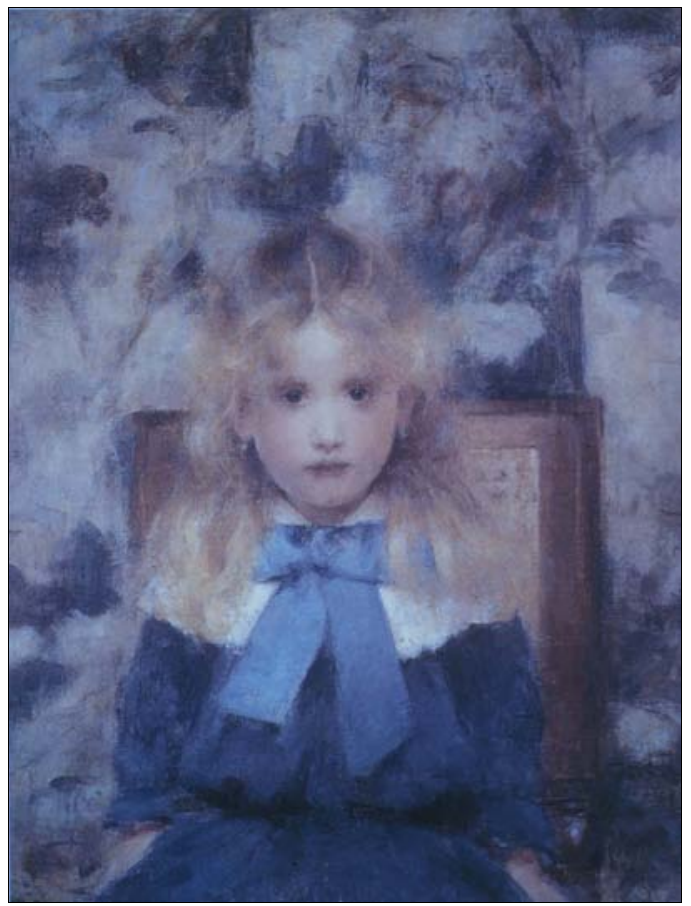

- Lám. 4. F. KHNOPFF, 1883. Mlle. Van der Hecht (Museos Reales de Bélgica, Bélgica) 


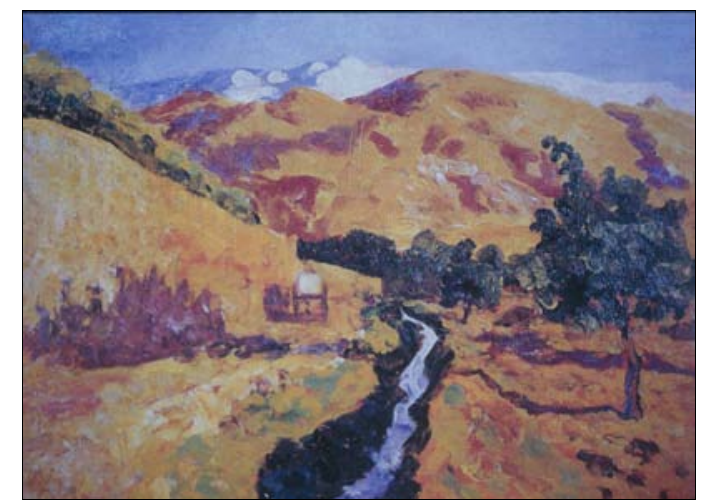

- Lám. 5. D. De Regoyos, Camino de los neveros, 1911 (colección privada).

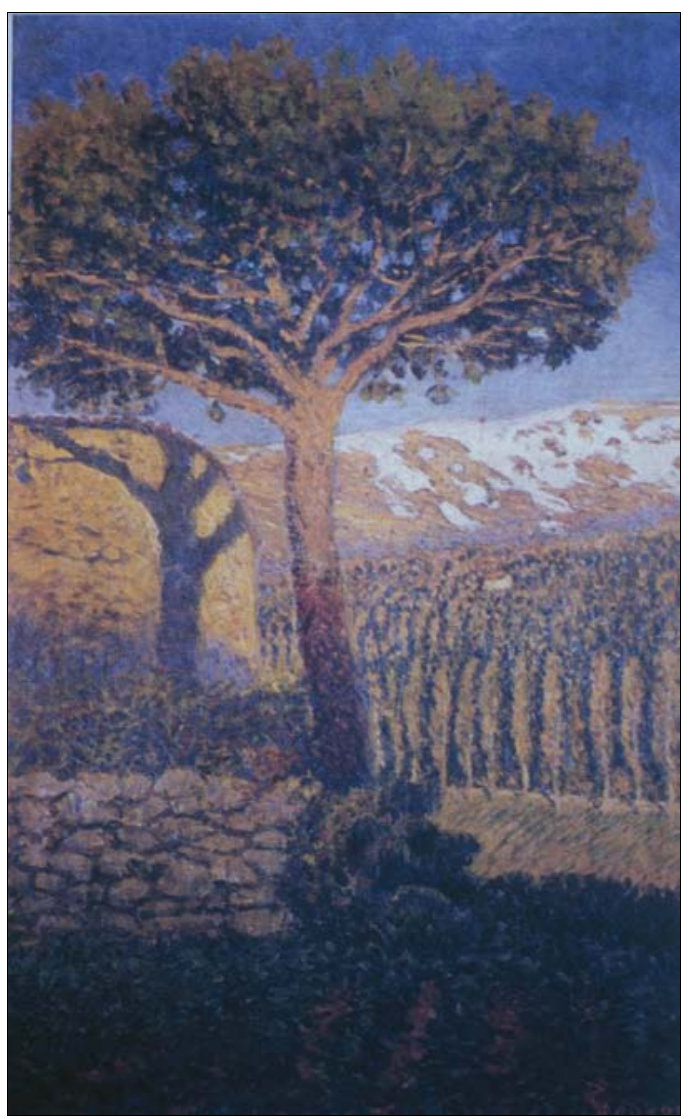

- Lám. 7. D. DE Regoyos, Pino y cumbres nevadas, 1900 (colección privada)

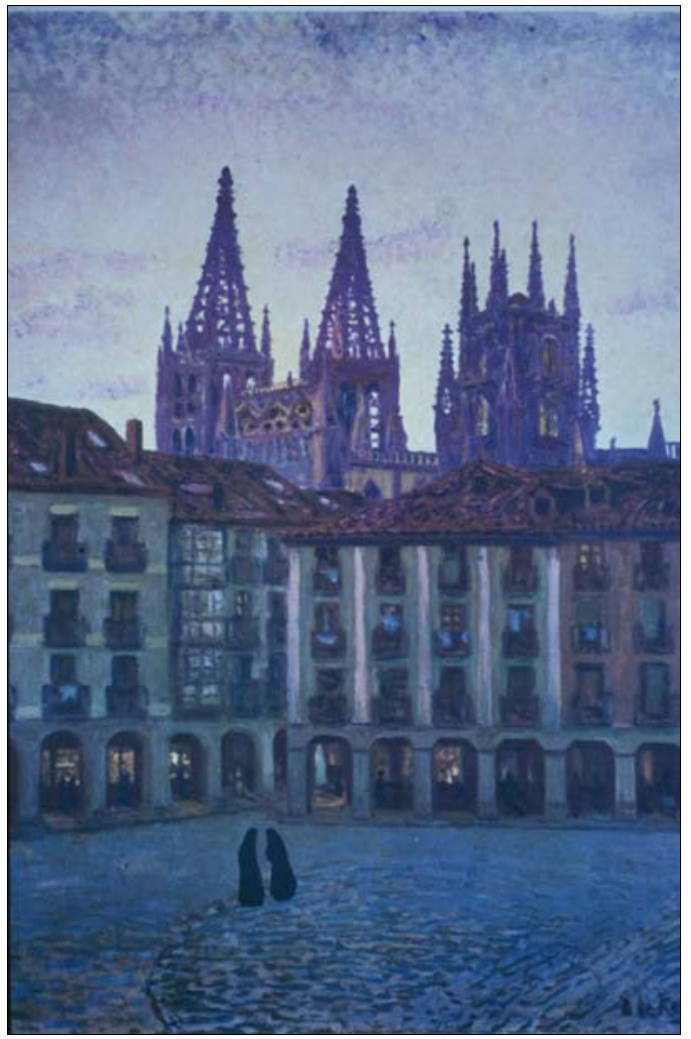

- Lám. 6. D. DE RegOYOS, Hora pálida, 1906 (colección privada)

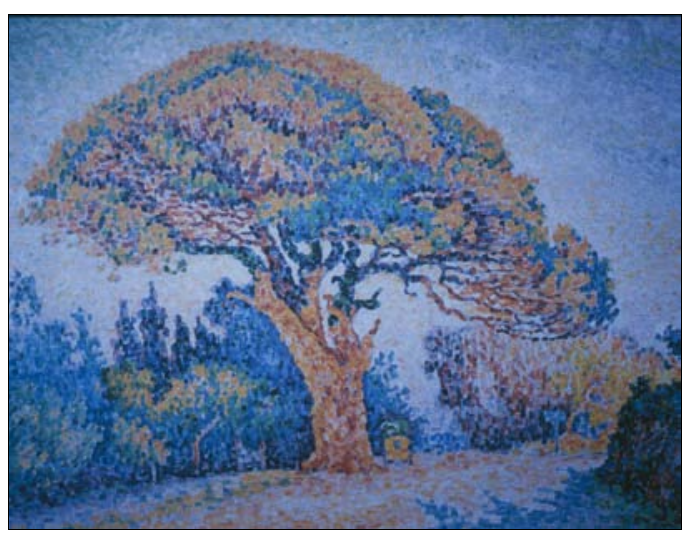

- Lám. 8. P. SignaC, Pino de Saint-Tropez, 1909 (Museo Pushkin, Moscú). 


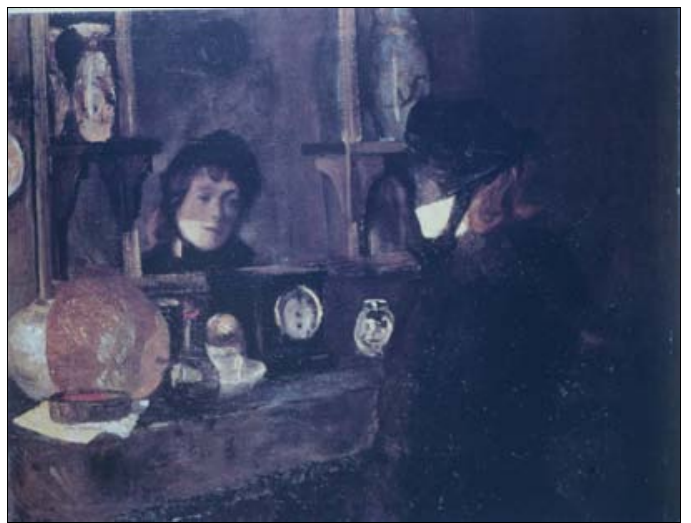

- Lám. 9. F. D. DE ReGoyos, Dama ante el espejo, 1885 (colección privada). 1885 (colección privada)

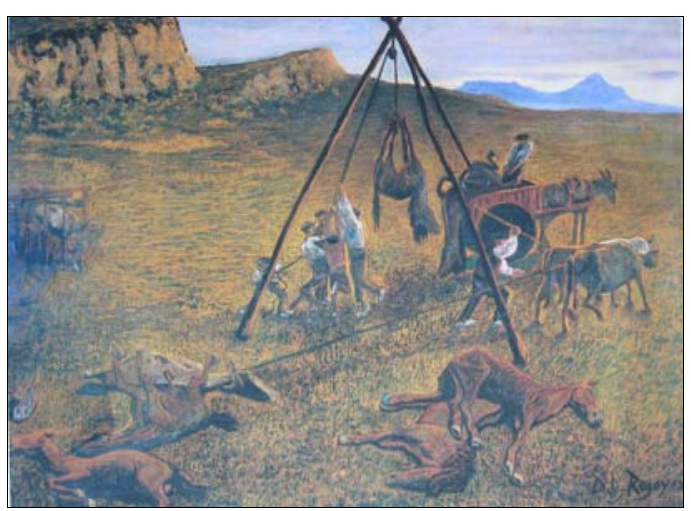

- Lám. 11. D. DE Regoyos, Víctimas de la fiesta, 1894 (Caja Astur).

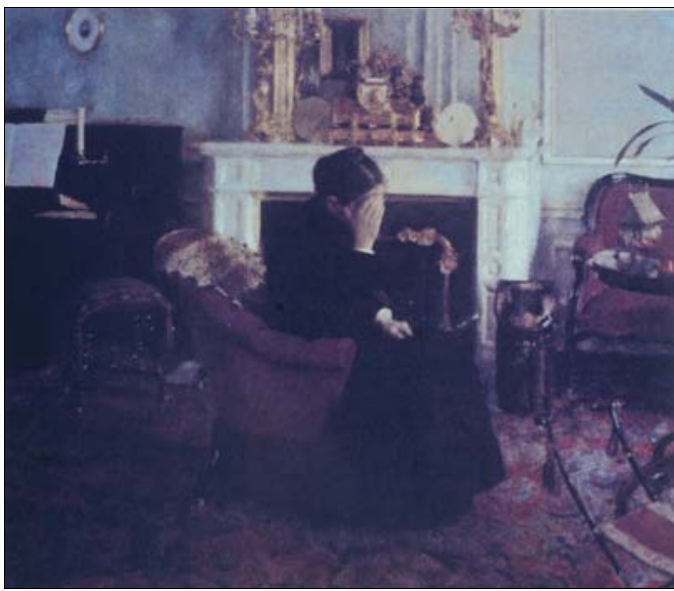

- Lám. 10. F. KHNOPFF, Escuchando a Schumann, 1883 (Museos Reales de Bélgica, Bruselas).

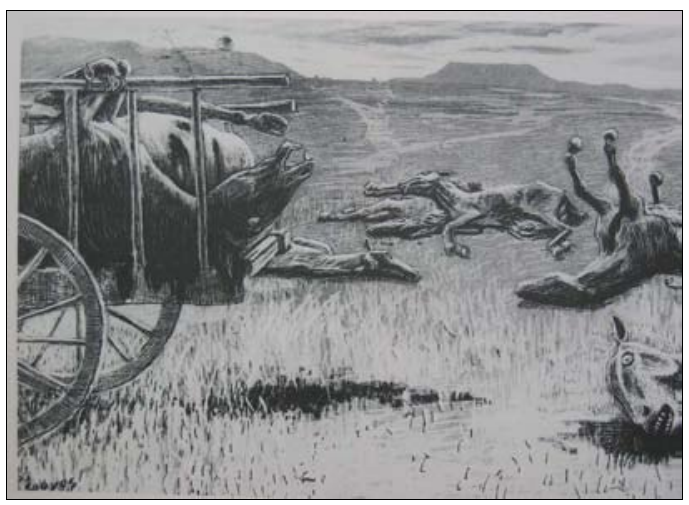

- Lám. 12. D. DE ReGOYOS, Víctimas de la fiesta, grabado (Casa Museo Abelló, Mollet del Mar).

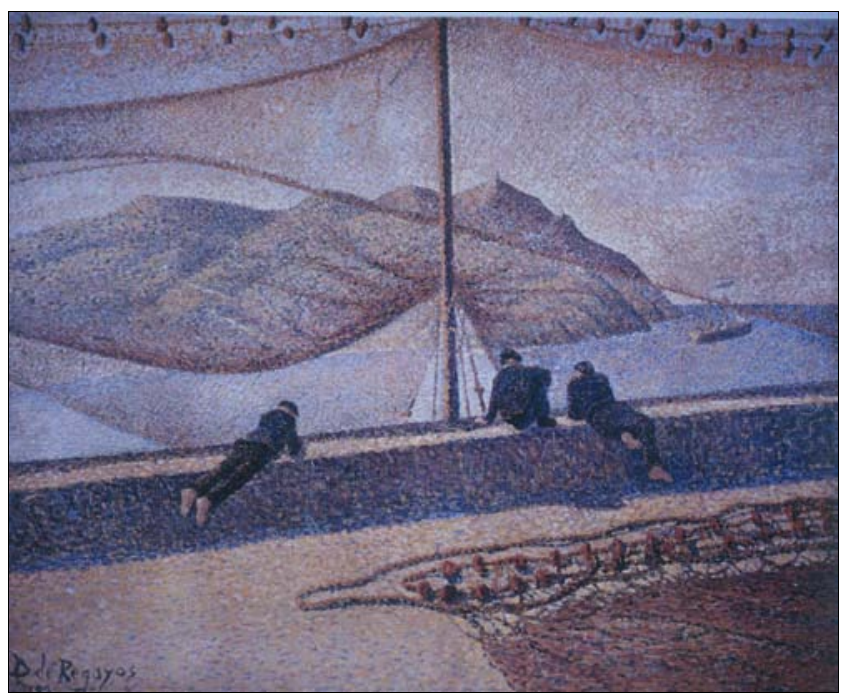

- Lám. 13. D. DE REGOYOS, Las redes, 1893 (colección privada). 


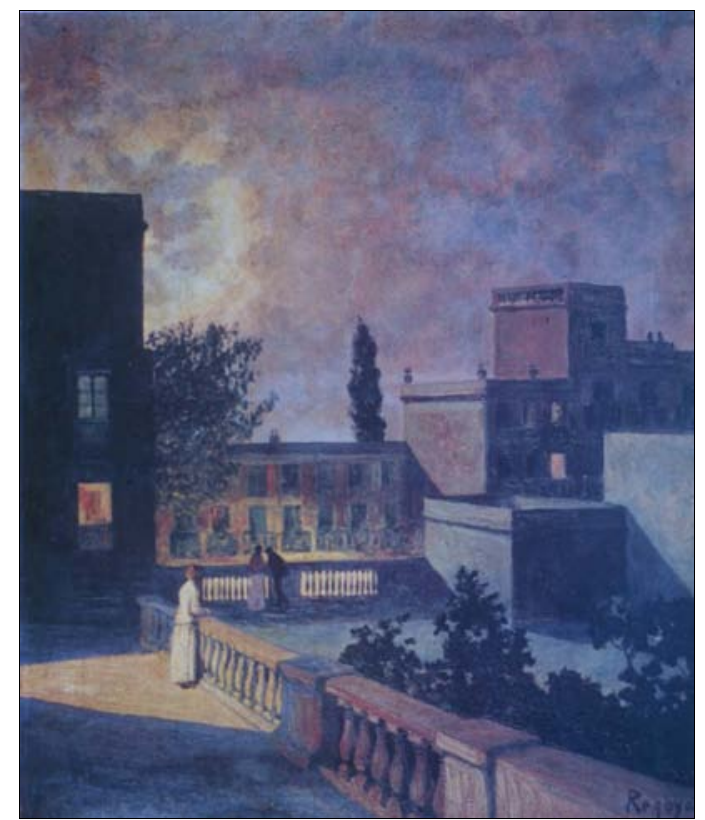

- Lám. 14. D. DE RegOYOS, Nocturno, 1899 (colección privada)

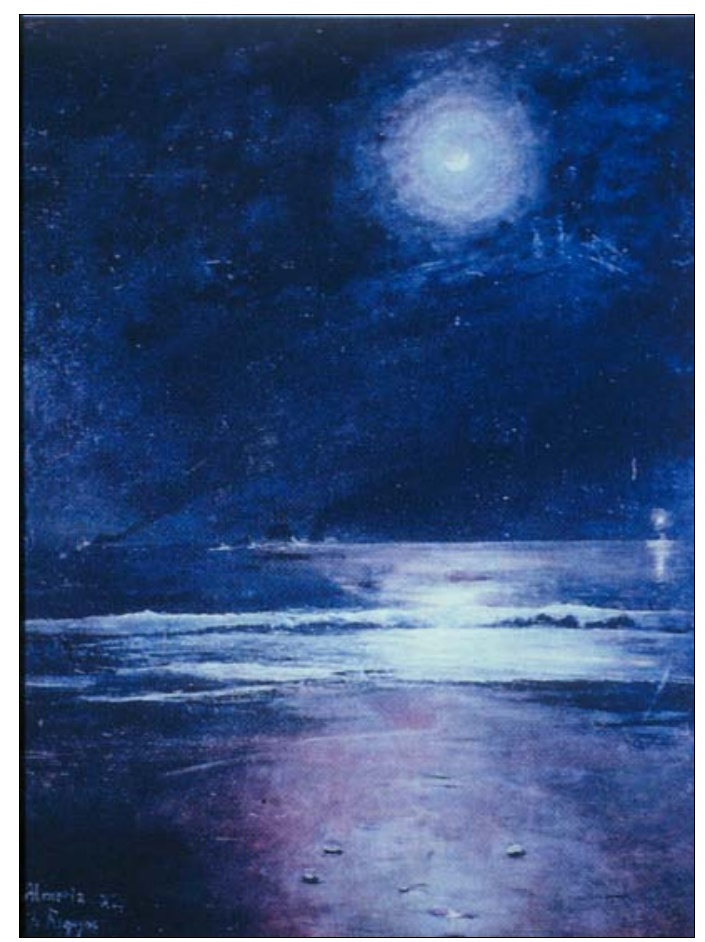

- Lám. 15. D. De Regoyos, Playa de Almería, 1882 (colección privada).

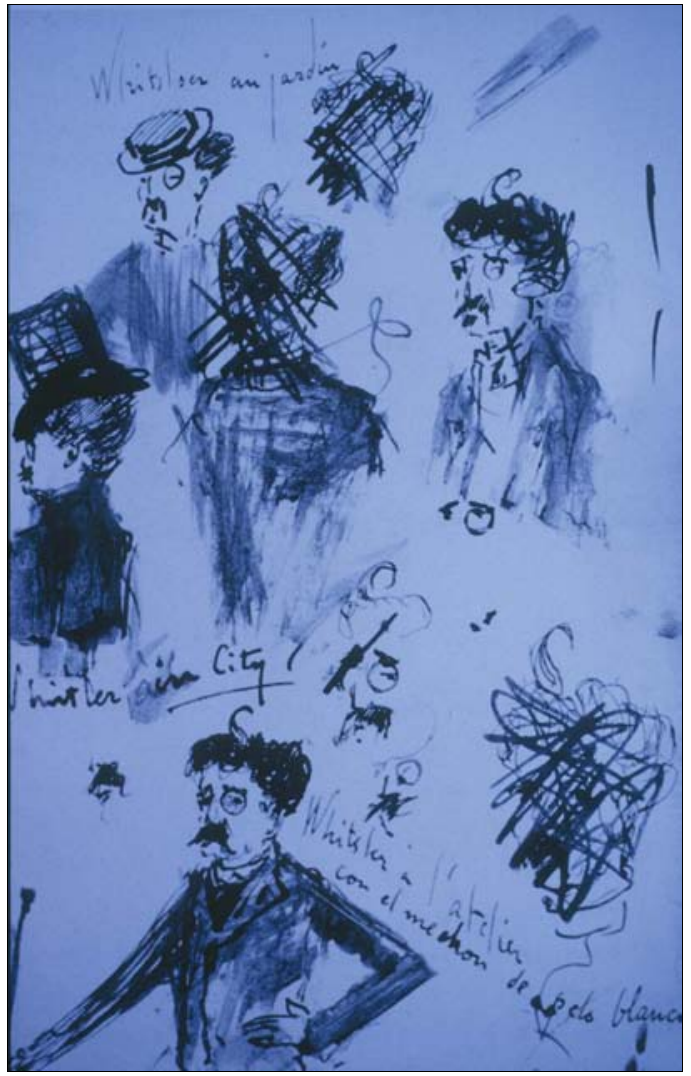

- Lám. 17. D. DE Regoyos, J.A. Mac. Whistler, 1885.

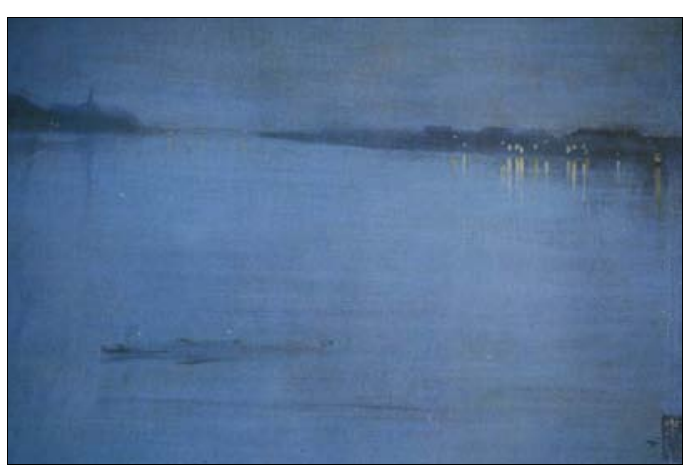

- Lám. 16. J. A. MC. WhistLeR, Azul y plata, 1870 (Tate Gallery, Londres). 


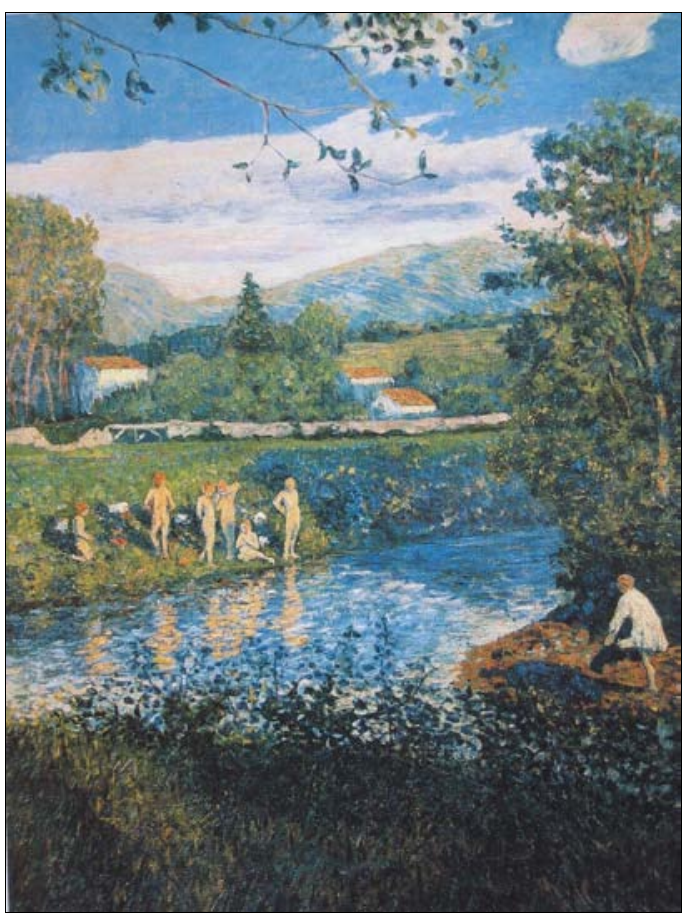

- Lám. 18. D. DE Regoyos, Baño en Rentería, 1899 (Museo de Bellas Artes de Bilbao).

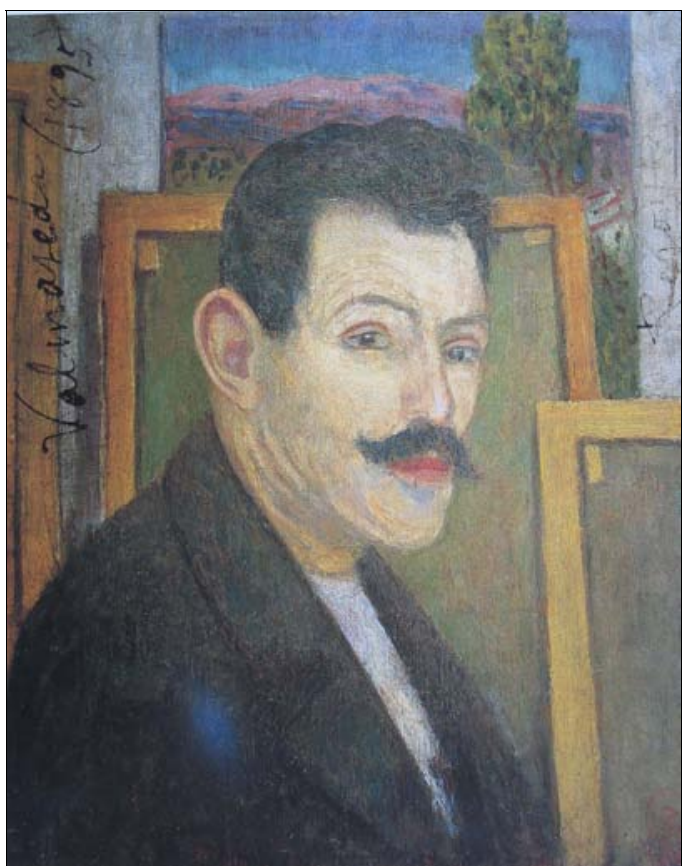

- Lám. 19. D. DE REGOYOS, Autorretrato, 1895 (Museo de Bellas Artes de Asturias. Oviedo). 